\title{
MEMBANGUN KARAKTER MULIA PADA ANAK MENURUT QS. LUQMAN 13-19
}

\author{
$\underline{\text { Safruroh }}$ \\ Universitas Islam Negeri (UIN) Sunan Kalijaga Yogyakarta \\ E-mail: safrurohalbatani@gmail.com
}

\begin{abstract}
This article elaborates some translations from the translators (mufassir) towards QS. Luqman: 13-19. The verse, furthermore, tells us the efforts done by Luqman al-Hakim to support his children a better education. There are some steps needed to be done to educate his children: aqidah education, religious education, dakwah education, and akblak education. It is additionally an effort to build the noble character in children.
\end{abstract}

Keywords: Noble Character, Childhood Education, Luqman al- Hakim

\section{PENDAHULUAN}

Anak merupakan amanat yang dititipkan Allah kepada orangtua. Mereka harus bertanggungjawab terhadap anak dihadapan Allah nanti. Allah telah menciptakan anak-anak dengan dibekali kekuatan pendorong alamiah yang dapat diarahkan ke arah yang baik maupun yang buruk. Karena itu sudah menjadi kewajiban orangtua untuk memanfaatkan kekuatan alamiah itu dengan menyalurkan kepada saluran yang baik, yakni dengan mendidik anak sejak usia dini untuk membiasakan diri dengan kelakukan dan adat istiadat yang baik, sehingga mereka tumbuh dan berkembang menjadi manusia yang kreatif dan dinamis, berguna bagi diri sendiri dan bagi pergaulan masyarakat sekelilingnya. Dalam QS. At-Tahrim: 6 Allah telah menegaskan: "Hai orang-orang yang beriman, peliharalah dirimu dan keluargamu dari api neraka."

Memelihara diri dan keluarga dari api neraka adalah dengan jalan memberi pelajaran dan pendidikan yang baik. Membiasakan mereka berkelakuan dan berakhlak mulia serta menunjukkan kepada mereka jalan yang membawa manfaat serta keuntungan dunia dan akhirat (Mahalli: 2002: 283284). Rasulullah telah menegaskan: "Berikanlah kendali kepada anak-anakmu, dan didiklah mereka dengan akhlak mulia." Pada hadis ini terdapat petunjuk tentang bagaimana orangtua harus mendampingi anak-anaknya, agar dapat mengawasi gerak-gerik tingkah laku mereka, sehingga bila terdapat penyelewengan dari jalan yang baik segera dapat diperhatikan dan dikembalikan ke jalan yang benar.

Keluarga merupakan faktor utama pembentuk kepribadian anak. Keluarga yang baik merupakan tempat paling aman dan nyaman bagi seluruh anggota keluarganya. Setiap anggota keluarga memiliki peranannya masing-masing. Salah satu anggota keluarga yang umumnya menjadi pusat perhatian dari anggota keluarga yang lain adalah anak. Seorang anak tentu saja harus terdidik dan terbina akhlaknya dengan baik sejak usia dini. Sebab hal ini akan mempengaruhi kehidupan dirinya di masa yang akan datang. Pendidikan menjadi salah satu upaya dalam membentuk karakter mulia pada anak.

Potensi ini sering diungkapkan Alquran yang dikaitkan dengan waktu penciptaan di mana Allah mengajari Adam tentang nama-nama (QS. Al-Baqarah: 31), mengajari manusia dengan pena 
(QS.Al-Alaq: 3-4), dan proses pendidikan di mana Allah telah mengajari manusia Alquran dan alBayan. (QS. Ar-Rahman: 4). Selain beberapa ayat yang disebutkan di atas, QS. Luqman: 13-19 juga memberikan gambaran tentang bagaimana sikap kita sebagai orangtua dalam mendidik anak-anak agar memiliki karakter yang mulia.

Kedudukan akhlak dalam kehidupan manusia menempati posisi yang penting, sebagai individu maupun masyarakat dan bangsa, sebab jatuh bangunnya suatu masyarakat tergantung kepada bagaimana akhlaknya. Apabila akhlaknya baik, maka sejahteralah lahir dan batinnya, apabila akhlaknya rusak, maka rusaklah lahir dan batinnya (Abdullah: 2007: 19-20).

\section{PENGERTIAN KARAKTER MULIA}

\section{a. Karakter}

Karakter secara harfiah berasal dari bahasa latin "carakter", yang antara lain berarti watak, tabiat, sifat-sifat kejiwaan, budi pekerti, kepribadian atau akhlak, secara etimologi akhlak adalah bentuk jamak dari khuluq yang berarti budi pekerti, perangai, tingkah laku, atau tabiat. Berakar dari kata khalaqa yang berarti menciptakan. Seakar dengan kata khaliq (pencipta), makhluk (yang diciptakan) dan khalaq (penciptaan) (Ilyas, 1999: 1).

Kesamaan akar kata di atas mengisyaratkan bahwa dalam akhlak tercakup pengertian terciptanya keterpaduan antara kehendak Allah dengan dengan perilaku manusia. Atau dengan kata lain, tata perilaku seseorang terhadap orang lain dan lingkungannya baru mengandung nilai akhlak yang hakiki manakala tindakan atau perilaku tersebut didasarkan kepada kehendak Allah. Dari pengertian etimologis seperti ini, akhlak bukan saja merupakan tata aturan atau norma perilaku yang mengatur hubungan antara manusia dengan Allah dan bahkan dengan alam semesta sekalipun (Nasution, 1992:98).

Pengertian akhlak biasanya disamakan dengan moral, budi pekerti, yaitu kelakuan, tabiat, watak atau sifat yang hakiki dari seseorang. Akhlak juga diartikan sebagai tata nilai yang bersifat azali yang mewarnai cara berfikir, bersikap dan bertindak seseorang terhadap dirinya sendiri, Allah dan Rasulnya, sesamanya serta lingkungan sekitar. Di sini menunjukkan bahwa sikap dan perilaku seseorang lebih didasarkan pada nilai dan norma agama (Zuriah: 2007:137).

"Watak" dalam pengertian di atas menunjukkan kualitas individu dalam mengaktualisasikan potensinya berupa sikap dan perilaku sesuai tuntunan hidup atas dasar nilai, norma, dan moral yang menjadi komitmennya, sedangkan kepribadian menunjukkan gambaran yang diberikan oleh masyarakat atas kualitas sikap dan perilaku individu sehari-hari atas dasar nilai, norma dan moral yang menjadi komitmen bersama.

Secara terminologis ada beberapa definisi tentang akhlak di antaranya: menurut Imam AlGhazali Akhlak adalah sifat yang tertanam dalam jiwa yang menimbulkan perbuatan-perbuatan dengan gampang dan mudah, tanpa memerlukan pemikiran dan pertimbangan (al-Ghazali, 1989: 58). Menurut Ibrahim Anis akhlak adalah sifat yang tertanam dalam jiwa, yang dengannya lahirlah macam-macam perbuatan, baik atau buruk, tanpa membutuhkan pemikiran dan pertimbangan (Anis, 1972: 202), sedangkan menurut Abdul Karim Zaidan akhlak adalah nilai-nilai dan sifat-sifat yang tertanam dalam jiwa, yang dengan sorotan dan pertimbangannya seseorang dapat menilai perbuatannya baik atau buruk, untuk kemudian memilih melakukan atau meninggalkannya (Zaidan, 1976:75).

Di samping istilah akhlak, juga dikenal istilah etika dan moral. Ketiga istilah itu sama-sama menentukan nilai baik dan buruk sikap dan perbuatan manusia. Perbedaannya terletak pada standar masing-masing. Bagi akhlak standarnya adalah Alquran dan sunnah, bagi etika standarnya adalah 
pertimbangan akal pikiran, dan bagi moral standarnya adat kebiasaan yang umum berlaku di masyarakat (Asmaran, 1992: 9).

Adapun karakter adalah ciri khas yang dimiliki oleh suatu benda atau individu. Ciri khas tersebut adalah asli dan mengakar pada kepribadian benda atau individu tersebut, serta merupakan" mesin" yang mendorong bagaimana seorang bertindak, bersikap, berucap, dan merespon sesuatu (Kertajaya, 2010:10).

Setiap individu memiliki ciri, sifat bawaan, dan karakteristik yang diperoleh dari pengaruh lingkungan sekitarnya. Ahli psikologi berpendapat bahwa kepribadian dibentuk oleh perpaduan faktor pembawaan dan lingkungan. Karakteristik bawaan, baik yang bersifat biologis maupun psikologis, dimiliki sejak lahir. Apa yang dipikirkan, dikerjakan, atau dirasakan seseorang, atau merupakan hasil perpaduan apa yang ada di antara faktor-faktor biologis yang diwariskan dan dipengaruhi lingkungan sekitarnya (Fatimah, 2006: 15).

Pendidikan karakter adalah sebuah sistem yang menanamkan nilai-nilai karakter pada peserta didik, yang mengandung komponen pengetahuan, kesadaran individu, tekad serta adanya kemauan dan tidnakan untuk melaksanakan nilai-nilai, baik terhadap Tuhan yang Maha Esa, diri sendiri, sesama manusia, lingkungan, maupun bangsa, sehingga akan terwujud insan kamil.

\section{b. Karakter Mulia}

Karakter mulia berarti individu memiliki pengetahuan tentang potensi dirinya, yang ditandai dengan nilai-nilai seperti reflektif, percaya diri, rasional, logis, kritis, kreatif dan inovatif, mandiri, hidup sehat, bertanggung jawab, cinta ilmu, sabar, berhati-hati, rela berkorban, pemberani, dapat dipercaya, jujur, ramah, cinta keindahan, individu juga memiliki kesadaran untuk berbuat yang terbaik atau unggul, dan individu juga mampu untuk bertindak sesuai potensi dan kesadrannya tersebut. Karakter adalah realisasi perkembangan positif sebagai individu (intelektual, emosional, sosial, etika dan perilaku) (Fatimah, 2006:16).

Individu yang berkarakter baik atau unggul adalah seseorang yang berusaha melakukan halhal yang terbaik terhadap Tuhan, dirinya, lingkungan, bangsa dan negara serta dunia internasional pada umumnya dengan mengoptimalkan potensi atau pengetahuan dirinya dan disertai dengan kesadaran, emosi dan motivasinya. Kehadiran agama Islam yang dibawa Nabi Muhammad diyakini dapat menjamin terwujudnya kehidupan manusia yang sejahtera lahir dan batin. Di dalamnya terdapat berbagai macam petunjuk tentang bagaimana seharusnya manusia itu menyikapi hidup dan kehidupan ini secara lebih bermakna dalam arti yang seluas-luasnya.

Akhlak yang baik ialah segala tingkah laku yang terpuji. Al-Ghazali menggunakan perkataan “munjiyat” yang berarti segala sesuatu yang memberikan kemenangan atau kejayaan. Akhlak yang baik dilahirkan oleh sifat-sifat yang baik. Oleh karena itu, dalam hal jiwa manusia dapat menelurkan perbuatan-perbuatan lahiriah. Tingkah laku dilahirkan oleh tingkah laku batin, berupa sifat dan kelakuan batin yang juga dapat berbolak-balik yang mengakibatkan berbolak-baliknya perbuatan jasmani manusia. Oleh karena itu, tindak-tanduk batin (hati) itupun dapat berbolak-balik (Abdullah: 2007:38).

Petunjuk agama mengenai berbagai kehidupan manusia yang berkaitan dengan tingkah laku manusia, tampak amat ideal dan agung. Islam mengajarkan kehidupan yang dinamis dan progresif, menghargai akal pikiran melalui pengembangan ilmu pengetahuan dan teknologi, bersikap seimbang dalam memenuhi kebutuhan material dan spiritual. Islam mengembangkan kepedulian sosial, menghargai waktu, bersikap terbuka, demokratis, berorientasi pada kualitas, egaliter, kemitraan, 
mencintai kebersihan, mengutamakan persaudaraan, berakhlak mulia, dan sikap-sikap positif lainnya. Dan untuk mewujudkan itu semua tentu anak butuh bimbingan arahan dan suri tauladan dari lingkungan sekitar terutama orangtua.

\section{HAL IHWALDAN $A S B \bar{A} B A L-N U Z \bar{U} \bar{L} Q S$. LUQMAN}

Wahbah Zuhayli menerangkan bahwa surat Luqman termasuk surat Makiyah, terdiri dari 34 ayat, diturunkan setelah surat ash-Shaffat. Sementara al-Qurtubi menyebutkan bahwa surat Luqman termasuk kelompok surat Makiyah, kecuali ayat 27-29 yang turun di Madinah (Zuhayli: 2003:135). Dinamakan surat Luqman karena dalam surat tersebut terdapat kisah Luqman, yang nama lengkapnya adalah Luqman bin Ba'ura, salah seorang putra dari Nabi Ayyub, termasuk suku Naubah dan merupakan bagian dari Masyarakat Ailah, yakni sebuah kota yang berada di sekitar laut Qulzum. Ia hidup pada masa Nabi Daud as. dengan julukan "al-hakim” (yang baik).

Mayoritas mufassir mempermasalahkan kedudukan Luqman,apakah ia seorang Nabi ataukah hanya hamba Allah yang shaleh yang diberi kelebihan hikmah. Dalam hal ini Imam Asy-Syaukani menjelaskan, mayoritas mufassirin menyimpulkan bahwa Luqman al-Hakim bukan seorang Nabi, tapi hamba Allah yang diberi kelebihan dari hamba lainnya, yakni diberi hikmah (Asy-syaukani: 1994:540), sedangkan anaknya bernama An'am atau Tsaran atau Asykan. Dari beberapa pendapat tersebut dapat diambil kesimpulan bahwa Luqman bukanlah seorang Nabi, tap hamba Allah yang shaleh yang telah diberi hikmah.

Sahabat Nabi Saw., Ibn Umar ra., menyatakan bahwa Nabi bersabda: “Aku berkata benar, sesungguhnya Luqman bukanlah seorang Nabi, tetapi dia adalah seorang hamba Allah yang banyak menampung kebajikan, banyak merenung dan keyakinannya lurus. Dia mencintai Allah maka Allah mencintainya, menganugerahkan kepadanya hikmah.

Penamaan surat ini dengan surat Luqman sangat wajar karena nama dan nasihat beliau yang sangat menyentuh diuraikan di sini dan hanya disebut dalam surat ini. Tema utamanya adalah ajakan kepada tauhid dan kepercayaan akan keniscayaan kiamat serta pelaksanaan prinsip-prinsip dasar agama. Al-Biqai berpendapat bahwa tujuan utama surat ini adalah membuktikan betapa kitab Alquran mengandung hikmah yang sangat dalam, yang mengantar pada kesimpulan bahwa yang menurunkannya adalah Allah (Shihab, 2002:273).

Mengenai asbāb al-nuzūl QS. Luqman: 13-19, Wahbah Zuhayli menjelaskan bahwa ada orang Quraisy datang kepada Rasulullah saw., yang meminta agar dijelaskan kepadanya berkaitan dengan kisah Luqman al-Hakim dan anaknya. Rasulullah pun membacakan surat Luqman, sedangkan pokok-pokok ajaran yang terkandung dalam surat tersebut terdiri dari: Pertama, keimanan kepada Allah, para nabi dan hari kiamat. Terkait dengan keimanan kepada Allah dijelaskan pula kekuasaan Allah, meliputi apa yang ada di langit dan di bumi, perputaran malam dengan siang dan lima masalah gaib yang pengetahuan akan hal tersebut hanyalah milik Allah. Kedua, kisah Luqman merupakan potret orangtua dalam mendidik anaknya dengan ajaran keimanan. Dengan pendidikan persuasif, Luqman dianggap sebagai profil pendidik bijaksana, sehingga Allah mengabadikannya dalam Alquran dengan tujuan agar menjadi pelajaran bagi para pembacanya. Ketiga, karakteristik manusia pembangkang. Allah menjelaskan tipe manusia pembangkang terhadap perintah Allah, hingga pada akhirnya mereka tidak mau mendengarkan Alquran (Zuhayili, 2003: 144). 


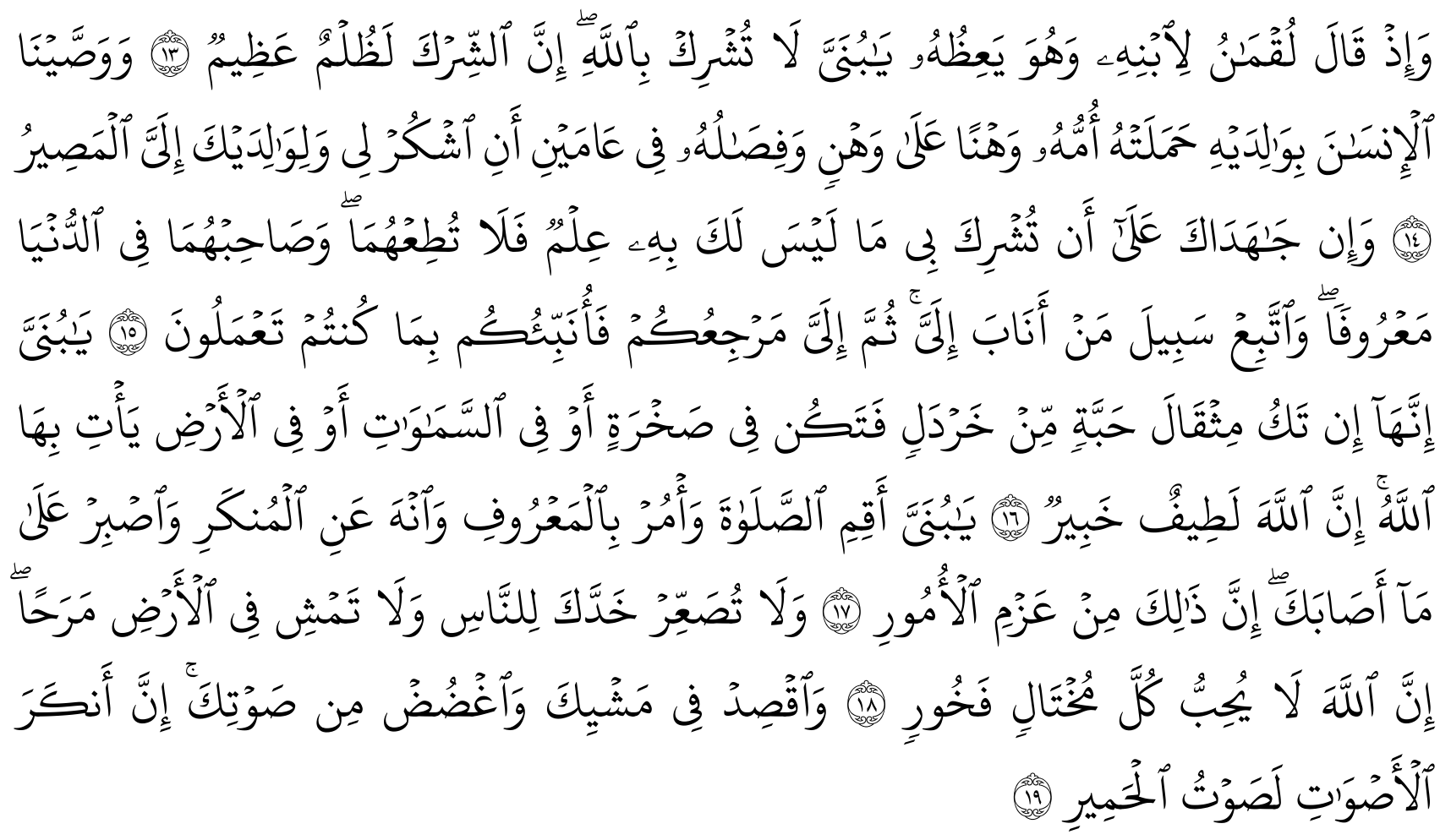

Menurut Quraish Shihab pada QS. Luqman: 13 ini, Luqman memulai nasihatnya dengan menekankan perlunyamenghindari syirik atau mempersekutukan Allah. Larangan ini sekaligus mengandung pengajaran tentang wujud dan keesaan Tuhan. Bahwa redaksi pesannya berbentuk larangan jangan mempersekutukan Allah untuk menekan perlunya meninggalkan sesuatu yang buruk sebelum melaksanakan sesuatu yang baik (menyingkirkan keburukan lebih utama daripada menyandang perhiasan. (Shihab, 2003:295-298).

Menurut Quraish Shihab kata “yaizhubu” terambil dari kata” wa'zh” yaitu nasihat menyangkut berbagai kebajikan dengan cara yang menyentuh hati, ada juga yang mengartikannya sebagai ucapan yang mengandung peringatan dan ancaman. Penyebutan kata ini sesudah kata "dia berkata" untuk memberi gambaran tentang bagaimana perkataan itu beliau sampaikan, yakni tidak membentak, tetapi penuh kasih sayang sebagaimana dipahami dari panggilan mesranya kepada anak. Kata ini juga mengisyaratkan bahwa nasihat itu dilakukannya dari saat ke saat, sebagaimana dipahami dari bentuk kata kerja masa kini dan datang pada kata "yaiz̧bubu" (Shihab, 2003).

Sementara menurut Muhammad Ali Ash-Shabuni, Allah menyebutkan sebagian nasihat dan petuah Luqman kepada putranya diawali dengan peringatan agar tidak syirik, dosa paling buruk dan hina, Allah berfirman: "Dan ingatlah ketika Luqman berkata kepada anaknya, diwaktu ia memberi pelajaran kepadanya: "hai anakku, janganlah kamu mempersekutukan Allah," sebutkanlah kepada kaummu nasehat Luqman Al-Hakim untuk memberi nasihat dan petunjuk kepadanya: "Anakku jadilah kamu orang yang pandai dan janganlah kamu mempersekutukan siapapun dengan Allah, baik manusia, patung atau anak. Sesungguhnya mempersekutukan Allah adalah benar-benar kedzahilaman yang besar," syirik itu menjiijkkan dan kedzhaliman yang fatal, sebab meletakkan sesuatu bukan pada tempatnya. Barang siapa menyamakan antara pencipta dan makhluk, antara Tuhan dan berhala, pasti dia orang yang paling tolol, paling tidak masuk akal, berhak disebut orang dzalim dan layak dimasukkan dalam kategori binatang (Ash-Shabuni, 2011:168-169). 
Ibn Katsir berpendapat bahwa Allah berfirman mengabarkan tentang wasiat Luqman kepada puteranya yaitu Luqman bin Anqa bin Sadun, sedangkan nama putranya adalah Tsaran. Luqman memberikan wasiat kepada puteranya yang merupakan orang yang paling dikasihi dan dicintainya, dan ini hakikat dianugerahkannya ia dengan sesuatu yang paling utama. Untuk itu pertama-tama ia memberikan wasiat untuk beribadah kepada Allah yang Maha Esa yang tidak ada sekutu bagi-Nya. Kemudian dia memperingatkan: "sesungguhnya, mempersekutukan Allah adalah benar-benar kedzaliman yang besar," yakni syirik adalah kedzhaliman yang terbesar (Katsir, 2008:202-204).

Sementara pada ayat 14, Quraish Shihab berpendapat bahwa ayat ini dinilai oleh banyak ulama bukan bagian dari pengajaran Luqman kepada anaknya. Ia disisipkan Alquran untuk menunjukkan betapa penghormatan dan kebaktian kepada kedua orangtua menempati tempat kedua setelah pengagungan kepada Allah. Memang Alquran seringkali menggandengkan perintah menyembah Allah dan perintah berbakti kepada kedua orangtua (QS. Al-An'am:15 dan Al-Isra ayat 23). Tetapi, menurut Quraish Shihab, kendati nasihat ini bukan nasihat Luqman, itu tidak berarti bahwa beliau tidak menasehati anaknya dengan nasehat serupa. Al-Biqai menilainya sebagai kelanjutan dari nasihat Luqman. Ayat ini, menurutnya bagaikan menyatakan bahwa Luqman menyatakan hal itu kepada anaknya sebagai nasihat kepadanya (Shihab, 2003:299-302).

Menurut Ibn Katsir setelah Luqman menasehati anaknya agar tidak berbuat syirik. Kemudian ia mengiringi wasiat kepada anak-anaknya untuk beribadah kepada Allah dengan berbakti kepada kedua orangtua (Katsir, 2008:205-206).Dalam menjelaskan keharusan berbuat baik kepada orangtua disertai penjelasan tentang susah-payahnya orangtua mengurus anak, mulai dari mengandung sampai menyapihnya selama dua tahun. Keharusan berbuat baik kepada orangtua juga dibatasi oleh aturanaturan Allah dan dalam kondisi yang paling pahit, jika orang yang paling berjasa dalam hidup mengajak untuk tidak taat kepada Allah, maka ajakan tersebut harus ditolak, dengan catatan tetap menjaga hubungan baik.

Dengan demikian, dapat dikatakan bahwa ayat ini mengindikasikan adanya penanaman rasa menghargai atau syukur kepada sesama manusia, meskipun syukur kepada manusia dibatasi normanorma Ilahi yang tidak boleh dilanggar. Sebab kecintaan yang berlebihan kepada seseorang bisa menjerumuskan kepada kemusyrikan yang disebut dengan al-ghulw.

Menurut Quraish Shihab pada ayat 15 ini diuraikan kasus yang merupakan pengecualian menaati perintah kedua orangtua, sekaligus menggaris bawahi wasiat Luqman kepada anaknya tentang keharusan meninggalkan kemusyrikan dalam bentuk serta kapan dan dimanapun. Ayat ini memerintahkan untuk tidak memutuskan hubungan dengan kedua orangtua atau tidak menghormatinya, tetapi tetaplah berbakti kepada keduanya selama tidak bertentangan dengan ajaran agamamu dan pergaulilah keduanya di dunia yakni selama mereka hidup dan dalam urusan keduniaan, bukan akidah dengan cara pergaulan yang baik. Tetapi jangan sampai hal ini mengorbankan masalah agama (Shihab, 2003:303-305).

Dari sisi redaksi, pesan berbuat baik kepada kedua orangtua menggunakan gaya bahasa ithnab, yakni diungkapkan dengan redaksi cukup panjang dengan penjelasan-penjelasan rasional, sehingga dapat menyentuh kalbu dan diakhiri dengan kesimpulan pendek إلي المصير (ilayy al-mas $\} i>r$ ). Kalimat itu merupakan suatu ungkapan yang mengindikasikan semua jerih payah dan pengorbanan hidup tidak sia-sia, sebab Allah akan membalasnya sesuai dengan perbuatan tersebut. Jika dikaitkan dengan dunia pendidikan, hal itu memberi gambaran, bahwa dalam kegiatan belajar-mengajar harus diciptakan iklim saling hormat-menghormati. 
Quraish Shihab berpendapat kewajiban menghormati dan menjalin hubungan baik dengan ibu bapak menjadikan sementara ulama berpendapat bahwa seorang anak boleh saja membelikan untuk ibu bapaknya yang kafir dan fakir minuman keras kalau mereka telah terbiasa dan senang meminumnya karena meminum-minuman keras buat orang kafir bukanlah sesuatu yang mungkar (Shihab, 2003).

Padaayat 16 surat Luqman, menjelaskan tentang wasiat Luqman kepada anaknya berkaitan dengan kedalaman ilmu Allah, yang diisyaratkan pula oleh penutup ayat lalu dengan pernyataan-Nya: "maka Ku beritakan kepada kamu apa yang telah kamu kerjakan". Luqman berkata: "Wahai anakku, sesungguhnya jika ada sesuatu perbuatan baik atau buruk walau sebesar biji sawi dan berada pada tempat yang paling tersembunyi. Allah akan memperhitungkannya dan memberi balasan. Dapat dikatakan bahwa kalau sebelumnya ayat ini berbicara tentang keesaan Allah dan larangan mempersekutukan-Nya, ayat ini menggambarkan kekuasaan Allah melakukan perhitunganperhitungan atas amal-amal perbuatan manusia di akhirat nanti (Shihab, 2003:306-308).

Menurut hemat penulis dalam hal ini Luqman mengilustrasikan, kalaulah ada aktifitas yang setara dengan biji sawi atau yang paling kecil berlokasi di bukit batu, di langit maupun di bumi atau di manapun, maka Allah Maha Mengetahui. Sifat lathif menunjukkan sesuatu yang tidak bisa terdeteksi oleh panca indera manusia, sedangkan khabir menginformasikan sesuatu yang tidak nampak. Penggandengan kedua asma ul-busna mengindikasikan adanya keikhlasan dalam melaksanakan berbagai aktifitas.

Selanjutnya pada ayat 17, menurut Quraish Shihab Luqman melanjutkan nasehatnya kepada anaknya nasehat yang dapat menjamin kesinambungan Tauhid serta kehadiran Ilahi dalam kalbu anak. Beliau berkata sambil tetap memanggilnya dengan panggilan mesra: "wahai anakku sayang, laksanakanlah shalat dengan sempurna syarat dan rukunnya dan sunnah-sunnahnya. Dan, disamping engkau memperhatikan dirimu dan membentenginya dari kekejian dan kemungkaran, anjurkan pula orang lain berlaku serupa. Karena itu, perintahkanlah secara baik-baik siapapun yang mampu engkau ajak mengerjakan yang ma'ruf dan cegahlah mereka dari kemungkaran (Shihab, 2003: 308).

Wahbah Zuhayli menjelaskan bahwa penegakan nilai-nilai shalat dalam kehidupan merupakan manifestasi dari ketaatan kepada Allah. Shalat merupakan komunikasi antara hamba dengan khalik-Nya, semakin kuat komunikasi tersebut, semakin kukuh keimanannya. Demikian halnya dengan amar ma'ruf nahi mungkar, ia merupakan wujud kepedulian terhadap keselamatan sesama. Upaya amar ma'ruf nahi mungkar membutuhkan stamina yang kuat, sebab ia mengandung resiko yang cukup berat. Oleh karena itu, pada akhir ayat ada perintah untuk bersikap sabar dalam kondisi apapun dan jangan keluar dari taat kepada Allah (Zuhayli, 2003: 154). Selanjutnya, Zuhayli menjelaskan bahwa kalimat ذلك من أزم الامور (inna $z \backslash a>l i k a$ min 'azmial-umu>r) mengandung pengertian bahwa kewajiban menegakkan nilai-nilai shalat dan amar ma'ruf nahi mungkar merupakan dua kewajiban yang harus dilaksanakan sebagai manifestasi dari 'abdan syakura.

Sedangkan pada ayat 18-19, Quraish Shihab menyatakanbahwaayat ini berisi tentang nasihat Luqman berkaitan dengan akhlak dan sopan santun berinteraksi dengan sesama manusia. Materi pelajaran akidah, beliau selingi dengan materi pelajaran akhlak, bukan saja agar peserta didik tidak jenuh dengan satu materi, tetapi juga untuk mengisyaratkan bahwa ajaran akidah dan akhlak merupakan satu kesatuan yang tidak dapat dipisahkan (Shihab, 2003: 311).

Untuk melaksanakan tugas berat perlu disertai dengan akhlak mulia, yakni saling menghargai dan menghormati sesama manusia yang dilandasi taat kepada Allah. Akhlak sesama manusia tersebut diungkapkan dengan gaya bahasa kinayah. Dalam ayat 18 diungkapkan ولا تصعر خدك للناس ولاتمش فن الأرض 
L مر(wala $>$ tus $\} a$ '-ir khaddaka li al-na $>$ s wala $>$ tamsyi fi al-ard\}i maraha $>$ ). Ayat tersebut mengandung larangan terhadap sifat takabur dihadapan orang lain, lantaran sikap tersebut wujud manusia musyrik, bukan hamba yang syukur. Pada ayat ke-18, larangan takabur lebih ditekankan kepada hati, sedangkan ayat ke-19 lebih kepada perilaku yang nampak dilapangan. وقصد في مشيك (waqs\}id fi masy-yika) mempunyai makna sederhana dalam hidup dan kehidupan; sedangkan واغضض من صوتك (waghd\}ud\} min s\}autik) mempunyai arti menghargai orang lain dengan cara berkomunikasi secara baik. Bentuk-bentuk komunikasi yang baik diungkapkan dalam ungkapan qaulan kari>ma (perkataan yang mulia).

\section{PELAJARAN LUQMAN AL-HAKIM: UPAYA MENUMBUHKAN KARAKTER MULIA PADA ANAK}

Langkah-langkah Luqman dalam upaya mendidik anak-anaknya, sebagaimana yang diabadikan oleh Allah dalam QS. Luqman: 13-19. Luqman menekankan perhatiannya dalam pendidikan anaknya kepada beberapa aspek diantaranya:

\section{Pendidikan Tauhid}

Luqman menyadari bahwa pendidikan tauhid perlu ditanamkan kepada anak sedini mungkin. Anak diajak mengenal Allah dengan memperkenalkan bermacam-macam ciptaan-Nya. Pendidikan tauhid sangat penting sekali sebagai modal dasar bagi anak dalam menjalani roda kehidupan nanti. Luqman menyampaikan kepada puteranya untuk tidak berbuat syirik kepada Allah. Menurut Ibn Mandzhur, kata as-syirku (syaraka) terdiri dari tiga huruf: syin,ra, dan kaf. Kata yang dibangun oleh ketiga huruf tadi mempunyai makna dasar bercampur. Dari kata-kata tersebut terbentuk kata: pertama, "asy-syirkatu", yang berarti perkumpulan atau perusahaan patungan. Kedua, "asysyaraku", yang berarti tali yang dianyam menjadi jala atau perangkat. Ketiga, "latamun syurakiyyun" berarti tamparan yang dikombinasi dengan pukulan. Keempat, "syukurun", berarti "jalan yang bercabang". Kelima, "syarika", yang berarti "putus tali ikatan" seperti dalam ungkapan orang Arab:"syarikat in-na'lu," (putus tali pengikat sandal). Keenam, "rajulun musytarakun", berarti “orang yang berbicara ngaco atau mengigau” (Mandzhur, tt: 100).

Dari makna dasar ini, Saleh Fauzan mendefinisikan syirik dengan penyimpangan dalam ibadah kepada Allah. Selanjutnya Fauzan membagi syirik menjadi dua macam: pertama, syirik akbar yakni yang dapat mengeluarkan seseorang dari Islam; kedua, syirik asghar, yakni penyimpangan dalam perilaku ibadah (Fauzan, 1997: 74-76).

Larangan syirik yang disertai dengan ancaman merupakan keharusan hanya taat dan patuh pada Allah. Jika ayat larangan syirik dikaitkan dengan konsep taskhir dalam QS. Luqman: 20, maka dapat dipahami bahwa syirik berarti manusia tunduk pada alam atau dikuasai alam.Dan jika manusia dikuasai alam, maka bisa diidentikkan dengan kebodohan, kemiskinan, dan keterbelakangn. Padahal, tauhid menuntut manusia yang harus menguasai alam. Konsekuensi dari tauhid: manusia harus menguasai ilmu pengetahuan dan teknologi berdasar hukum alam sehingga benar-benar menjadi khalifah di muka bumi.

Dari segi redaksi, ayat tersebut diawali dengan kata ya> bunayya. Dalam bahasa Arab ini termasuk at-tasghir lil-isyfaq wa tahabbub, panggilan kesayangan yang menunjukkan rasa cinta amat dalam dari orangtua kepada anaknya (Zuhayli, 2003: 163-164). Ayat ini mengindikasikan bahwa seorang pendidik yang baik harus memahami karakteristik anak didiknya serta menghargainya dengan baik. Larangan berbuat syirik diungkapkan dengan fi'il mudhari' yang mengindikasikan lil-istimrar, dalam arti, sejak dini para pendidik harus menciptakan lingkungan yang kondusif agar terbebas dari situasi dan 
kondisi yang menjerumuskan pada kemusyrikan, serta mendorong anak didiknya agar terus-menerus mencari ilmu.

\section{Pendidikan Ibadah}

Setelah tauhid ditanamkan kepada anak, Luqman mengajaknya membiasakan diri melakukan ibadah yang diperintahkan oleh Allah dan Rasul-Nya. Sesuatu betapapun ringannya, kalau tidak di biasakan akan terasa berat. Sebaliknya sesuatu yang berat kalau dibiasakan terasa ringan. Pertama Luqman memerintahkan anaknya mendirikan shalat karena shalat adalah tiang agama dan menjadi barometer ketaqwaan seseorang kepada Allah (Ilyas, 2006: 180).

Rasulullah saw. mengajarkan kepada orangtua untuk menyuruh anaknya mendirikan shalat pada umur tujuh tahun, dan memberikan sanksi pada umur sepuluh tahun bila masih belum mau mendirikan shalat.

"Suruhlah anakmu shalat di waktu mereka berumur tujuh tahun, pukullah mereka (jika tidak mau mengerjakan) setelah berumur sepuluh tahun, dan pisahkanlah tidur mereka darimu."(HR. Abu Daud).

Tentu saja disiplin ibadah baru bisa dilaksanakan di tengah keluarga apabila bapak atau ibu terlebih dahulu melaksanakannya. Disiplin yang ditanamkan dari kecil oleh orangtua akan meninggalkan bekas yang lama, hingga nantinya akan tidak mudah tergoda meninggalkan perintahperintah Allah.

\section{Pendidikan Dakwah}

Luqman menanamkan kepada anaknya sifat keberanian menyatakan kebenaran, dan mengajak orang untuk melakukannya, serta keberanian menunjukkan mana yang salah. Dan melarang orang untuk mendekatinya. Inilah sikap da'i yang tidak mementingkan dirinya sendiri tetapi juga memperhatikan lingkungan sekitarnya. Apabila setiap orang berusaha amar ma'rif dan nahi mungkar tentu dunia ini akan penuh dengan kedamaian, silang sengketa akan bisa diatasi.

\section{Pendidikan Akhlak}

Suatu tugas mau tidak mau harus mempunyai konsekuensi dan resiko. Resiko seorang dai' adalah mendapatkan tantangan dari masyarakat atau pribadi yang tidak senang. Untuk itu seorang dai' harus siap mental menerima segala macam cobaan, tidak mudah mundur dan patah semangat, harus memperlihatkan akhlak seorang yang teguh iman dan sabar. Luqman mengingatkan anaknya untuk bersabar menerima segala macam cobaan.

Karenanya, kehidupan muslim yang baik dapat menyempurnakan akhlaknya sesuai dengan yang telah dicontohkan oleh Rasulullah. Akhlak yang baik dilandasi oleh ilmu, iman, amal, dan takwa. Ia merupakan kunci bagi seseorang untuk melahirkan perbuatan dalam kehidupan yang diatur oleh agama. Dengan ilmu, iman, amal, dan takwa seseorang dapat berbuat kebajikan, seperti shalat, puasa, berbuat baik kepada sesama manusia, dan kegiatan-kegiatan lain yang merupakan interaksi sosial. Sebaliknya tanpa ilmu, iman, amal, dan takwa, seseorang dapat yang tidak sesuai dengan akhlak yang baik.

Dari sisi redaksi, secara keseluruhan nasihat Luqman berisi sembilan perintah, tiga larangan dan tujuh argumentasi. Kesembilan perintah tersebut adalah: 1) berbuat baik kepada orangtua; 2) syukur kepada Allah dan orangtua; 3) berkomunikasi dengan baik kepada orangtua; 4) mengikuti pola 
hidup para nabi dan orang-orang shaleh; 5) menegakkan shalat; 6) amar ma'ruf; 7) nahi mungkar; 8) sederhana dalam kehidupan, dan; 9) bersikap sopan dalam komunikasi. Sementara yang berbentuk larangan adalah, 1) larangan syirik; 2) larangan bersikap sombong, dan; 3) larangan berlebihan dalam kehidupan.

Adapun ketujuh argumentasi tersebut adalah: 1) barang siapa bersyukur, sungguh syukurnya itu untuk dirinya sendiri, dan barangsiapa kufur, sesungguhnya Allah maha kaya dan Maha terpuji; 2) sesungguhnya syirik itu merupakan kedzhaliman yang besar; 3) kepada-Nya manusia dikembalikan, untuk mempertanggung jawabkan apa yang telah diperbuatnya selama hidup di dunia; 4) sesungguhnya Allah maha mengetahui segala sesuatu; 5) sesungguhnya semuanya itu merupakan 'azm il-umur, 6) sesungguhnya Allah tidak menyukai orang yang sombong, dan; 7) sesungguhnya sejelek-jelek suara adalah suara keledai.

Apa yang dilakukan oleh Luqman dalam mendidik anak-anaknya menjadi salah satu contoh bagi para pendidik, baik orangtua maupun guru. Sebagai kitab petunjuk bagi manusia, Alquran dapat dipahami oleh manusia dengan segala variasi dan perbedaan tingkat kemampuan dan kondisi jiwa mereka, termasuk umur, intelektual, kultur dan pengalaman batinnya.

Seluruh kandungan Alquran, yang berupa larangan, perintah, anjuran atau berita, merupakan risalah yang disampaikan kepada manusia. Karenanya isi kandungannya jelas memiliki dimensi kemanusiaan, baik secara sosiologis maupun psikologis. Proses pewahyuan serta model seruan Alquran kepada manusia adalah tipe proses pengajaran yang ideal. Sementara isi dan muatannya merupakan materi pendidikan yang ideal dan utama, meskipun dalam pengungkapannya, Alquran tetap dalam sifatnya yang universal (Suyudi, 2005:14).

\section{SIMPULAN DAN PENUTUP}

Setelah melihat beberapa penafsiran yang dilakukan oleh para mufassir berkaitan dengan QS. Luqman: 3-19. Bisa disimpulkan bahwa upaya yang dilakukan oleh Luqman dalam mendidik anakanaknya diabadikan oleh Allah, sehingga menjadi nama sebuah surat dalam Alquran. Dalam ayat tersebut terlihat dengan jelas bagaimana dan apa yang harus dilakukan oleh orangtua dalam upaya menumbuhkan karakter mulia pada anak. Hal pertama yang dilakukan oleh Luqman adalah pendidikan tauhid. Yaitu larangan untuk menyekutukan Allah atau larangan untuk berbuat syirik.Selanjutnya secara bertahap Luqman menanamkan nilai-nilai yang lain yang harus dilakukan oleh orangtua dalam menanamkan nilai-nilai pendidikan kepada anaknya, yaitu pendidikan ibadah, pendidikan dakwah, dan pendidikan akhlak. Beserta cara-cara yang harus dilakukan oleh orangtua untuk mewujudkan beberapa nilai tersebut agar tertanam pada anak.

\section{REFERENSI}

Abdullah, Yatimin. 2007.Studi Akblak dalam Perspektif Alquran. Jakarta: Amzah

Anis, Ibrahim. 1972. al-Mu'jam al-Wasith. Kairo: Dar al-Ma'arif.

Asmaran. 1992. Pengantar Studi Akblak. Jakarta: Rajawali Pers.

Fauzan, Saleh. 1997. Al-Irsyad ila Shabih al-Itiqad. Riyad: Dar al-Huzaemah.

Fatimah, Enung. 2006. Psikologi Perkembangan. Bandung: Pustaka Setia. 
al-Ghazali,Abu Hamid Muhammad. 1989.Ibya Ulum al-Din. Beirut: Dar al-Fikr.

Katsir, Ibn. 2008. Tafsir Ibn Katsir. Jilid VII. Jakarta: Pustaka Imam Syafi'i.

Kertajaya. 2010. Pendidikan Karakter. Jakarta: Gramedia.

Mahalli, Ahmad Mudjab. 2002. Membangun Pribadi Muslim. Jogjakarta: Menara Kudus.

Nasution, Harun. 1992.Ensiklopedi Islam Indonesia. Jakarta: Djambatan.

Mandzhur, Ibnu. 1200. Lisan al-'Arab. Beirut: Dar al-Mashadir.

Asy-Syaukani, Imam. 1994. Zubdat at-Tafsir. Damaskus: Ihwa Turas al-Islami.

Shihab, M. Quraish. 2003. Tafsir al-Misbah. Vol X. Ciputat: Lentera Hati.

Suyudi. 2005. Pendidikan dalam Perspektif Alquran. Yogyakarta: Mikraj.

Ash-Shabuni, Syaikh Muhammad. 2011. Rawa'u al-Bayan;Tafsir Ayat al-Abkam. Damaskus: Maktabah al-Ghazali.

Zuriah, Nurul. 2007.Pendidikan Moral dan Budi Pekerti dalam Perspektif Perubahan. Jakarta: Bumi Aksara.

Ilyas, Yunahar. 2006. Kuliah Akblak. Yogyakarta: Lembaga Pengkajian dan Pengamalan Islam (LPPI) UMY.

Zaidan, Abdul Karim. 1976.Ushul al-Da'wah. Baghdad: Jam'iyyah al-Amani.

Zuhayli, Wahbah. 2003. Tafsir Al-Munir. Beirut: Dar al-Fikr. 